\title{
Extreme storms during the last 6500 years from lagoonal sedimentary archives in the Mar Menor (SE Spain)
}

\author{
Laurent Dezileau$^{1}$, Angel Pérez-Ruzafa ${ }^{2}$, Philippe Blanchemanche ${ }^{3}$, Jean-Philippe Degeai ${ }^{3}$, Otmane Raji ${ }^{1,4}$, \\ Philippe Martinez ${ }^{5}$, Concepcion Marcos $^{2}$, and Ulrich Von Grafenstein ${ }^{6}$ \\ ${ }^{1}$ Geosciences Montpellier, Université de Montpellier, CNRS, UMR 5243, Montpellier, France \\ ${ }^{2}$ Departamento de Ecologia e Hidrologia, Regional Campus of International Excellence "Campus Mare Nostrum", \\ Universidad de Murcia, Murcia 30100, Spain \\ ${ }^{3}$ Laboratoire d'Archéologie des Sociétés Méditerranéennes, Université Montpellier 3, CNRS, UMR 5140, Montpellier, France \\ ${ }^{4}$ Department of Earth Sciences, Université MohammedV-Agdal, Rabat, Morocco \\ ${ }^{5}$ Université Bordeaux 1, EPOC, CNRS, UMR 5805, Bordeaux, France \\ ${ }^{6}$ Laboratoire des Sciences du Climat et de l'Environnement, CNRS/CEA, Saclay, France
}

Correspondence to: Laurent Dezileau (dezileau@gm.univ-montp2.fr)

Received: 10 February 2016 - Published in Clim. Past Discuss.: 18 February 2016

Accepted: 13 May 2016 - Published: 28 June 2016

\begin{abstract}
Storms and tsunamis, which may seriously endanger human society, are amongst the most devastating marine catastrophes that can occur in coastal areas. Many such events are known and have been reported for the Mediterranean, a region where high-frequency occurrences of these extreme events coincides with some of the most densely populated coastal areas in the world. In a sediment core from the Mar Menor (SE Spain), we discovered eight coarse-grained layers which document marine incursions during periods of intense storm activity or tsunami events. Based on radiocarbon dating, these extreme events occurred around 5250, $4000,3600,3010,2300,1350,650$, and 80 years cal BP. No comparable events have been observed during the 20th and 21 st centuries. The results indicate little likelihood of a tsunami origin for these coarse-grained layers, although historical tsunami events are recorded in this region. These periods of surge events seem to coincide with the coldest periods in Europe during the late Holocene, suggesting a control by a climatic mechanism for periods of increased storm activity. Spectral analyses performed on the sand percentage revealed four major periodicities of $1228 \pm 327$, $732 \pm 80,562 \pm 58$, and $319 \pm 16$ years. Amongst the wellknown proxies that have revealed a millennial-scale climate variability during the Holocene, the ice-rafted debris (IRD) indices in the North Atlantic developed by Bond et al. (1997, 2001) present a cyclicity of $1470 \pm 500$ years, which matches
\end{abstract}

the $1228 \pm 327$-year periodicity evidenced in the Mar Menor, considering the respective uncertainties in the periodicities. Thus, an in-phase storm activity in the western Mediterranean is found with the coldest periods in Europe and with the North Atlantic thermohaline circulation. However, further investigations, such as additional coring and highresolution coastal imagery, are needed to better constrain the main cause of these multiple events.

\section{Introduction}

In the last century the Mediterranean coastal zones have undergone a considerable development and the coastal disaster incidence has significantly increased. The coastal zones are exposed to flooding and coastal erosion processes and are highly vulnerable to extreme events, such as storms, cyclones, or tsunamis, that can cause significant losses (Seisdedos et al., 2013).

Intense storms and cyclones are rare meteorological phenomena observed in the Mediterranean Sea. Different climatological and meteorological works in the western Mediterranean area show that extreme storms and cyclones show a complex variability in the sense of non-uniform spatial and temporal patterns (Trigo et al., 2000; Lionello et al., 2006; Gaertner et al., 2007). This is in partly due to the lack of a 
clear large-scale pattern, which may be expected when dealing with intense events, as the number of events is low with irregular intensity and intervals. More long-term observations or palaeo-reconstructions in different areas of the western Mediterranean are needed. Tsunamis are known to occur in the Mediterranean Sea where all types of sources - earthquakes, volcanic eruptions, and landslides - from the continental margins are active. There is evidence of large tsunamis during the historical and prehistorical period, especially in the tectonically more active eastern Mediterranean (e.g. Kelletat and Schellmann, 2002; Morhange et al., 2006). The western part of the basin has also been reported as tsunamiexposed. Historic events have been reported from the Algerian coast, and tsunami propagation has been modelled (Álvarez-Gómez et al., 2011). Geomorphic evidence of ancient tsunami impacts has also been documented (Maouche et al., 2009). A long-term record of tsunami and storm activity on timescales of centuries to millennia is especially important in understanding the temporal variability of these extreme events.

This study focuses mainly on the Murcia province in Spain (Fig. 1). This lowland Mediterranean coast is sensitive to risks of submersion during extreme events. We propose to use a high-resolution geochemical and sedimentological approach to reconstruct past surge events in the Mar Menor and then compare our results with extreme historical coastal events in the western Mediterranean.

\section{Study site}

The Mar Menor is the largest lagoon on the Spanish Mediterranean coast, located in the SE of the Iberian Peninsula, in the region of Murcia in the area called Campo de Cartagena Basin (lat 37.786129, long 0.810450, Fig. 1). This coastal lagoon occupies an area of approximately $135 \mathrm{~km}^{2}$, with an average depth of $3.6 \mathrm{~m}$. This lagoon is separated from the Mediterranean sea by La Manga, which is a sandy barrier $20 \mathrm{~km}$ long, between 30 and $500 \mathrm{~m}$ wide, and less than $3 \mathrm{~m}$ above sea level. This sandy barrier is crossed by five, more or less functional, channels or "golas". The Campo deCartagena Basin occupies $1440 \mathrm{~km}^{2}$, with an elevation ranging from sea level to $1065 \mathrm{~m}$, surrounded by the Mediterranean Sea to the east, the anticline of Torrevieja to the north, and the Cartagena-La Unión mountain range to the south. This basin is filled by sediments from the early Miocene to the Quaternary. The major lithologies are composed of sand, silt, clay conglomerate, caliche, and sandstone of the Quaternary period and marl, conglomerate, and gypsum for the Miocene and Pliocene periods (Jiménez-Martinez et al., 2012). The lagoon and the northern salt marshes of San Pedro are protected because of their ecological importance (Special Protected Area of Mediterranean Interest, Natura 2000 network and Ramsar). The area is impacted by residual past mining activity, agricultural activities (intensive fruit and veg- etable production), and urban growth coupled with touristic development since 1956 (Pérez-Ruzafa et al., 1987, 1991, 2005). Most of the La Manga area is urbanized; a population of 10000 inhabitants live here all year long, growing to $\sim 200000$ inhabitants during summer. High population density and low-level topography make the area very sensitive to the impact of climate change and sea level rise. The Mar Menor is considered one of sites on the Spanish coast most threatened by the mean sea level rise and possible increase in extreme climatic events.

\section{Materials and methods}

\subsection{Core material}

A $4 \mathrm{~m}$ long piston core (MM2) was collected in the Mar Menor in September 2011 (Fig. 1) with the UWITEC $^{\odot}$ gravity coring platform (Laboratoire des Sciences du Climat et de l'Environnement and University of Chambery) using a simplified piston corer of $2 \mathrm{~m}$ length and $83 \mathrm{~mm}$ inner diameter. Two consecutive sections ( 0 to 2 and 2 to $4 \mathrm{~m}$ sediment depth, respectively) were cored from a first position followed by a third section ( 1 to $3 \mathrm{~m}$ ) from a position ca. $1 \mathrm{~m}$ away to cover the technical hiatus between the first two sections. The MM2 core was collected at $4 \mathrm{~m}$ below sea level.

\subsection{Physical measures}

Back in the laboratory, the structure of the sediment was studied using the Scopix X-ray scanning (EPOC, University of Bordeaux 1) and photographed. This was complemented by granulometric analyses on contiguous $1 \mathrm{~cm}$ samples using a Beckman-Coulter LS13320 laser diffraction particlesize analyser (Géosciences Montpellier). XRF (X-ray fluorescence spectrometry) analyses were performed on the surface of the split sediment core MM2 every $0.5 \mathrm{~cm}$ using a non-destructive Avaatech core scanner (EPOC, Université Bordeaux 1). The split core was covered with a $4 \mu \mathrm{m}$ thin Ultralene to avoid contamination. Geochemical data were obtained at different tube voltage: $10 \mathrm{kV}$ for $\mathrm{Al}, \mathrm{Si}, \mathrm{S}, \mathrm{Cl}, \mathrm{K}$, $\mathrm{Ca}, \mathrm{Ti}, \mathrm{Mn}$, and $\mathrm{Fe}$ and $30 \mathrm{kV}$ for $\mathrm{Zn}, \mathrm{Br}, \mathrm{Sr}, \mathrm{Rb}$, and $\mathrm{Zr}$ (Richter et al., 2006).

\subsection{Macrofauna}

To study mollusc shells, samples were taken every $2 \mathrm{~cm}$ and sieved at $1 \mathrm{~mm}$. Macrofauna samples were taken at fixed volume $\left(100 \mathrm{~cm}^{3}\right)$. Individuals were determined to the lowest taxonomic level possible (species or genera) and counted. Assemblage structure was estimated by mean of species richness $(S)$, taxon abundance $\left(n_{i}\right)$, and total abundance $(N)$.

\subsection{Geochronology}

The chronology of core MM2 was carried out using ${ }^{137} \mathrm{Cs}$ and ${ }^{210} \mathrm{~Pb}$ method on a centennial timescale by gamma spec- 


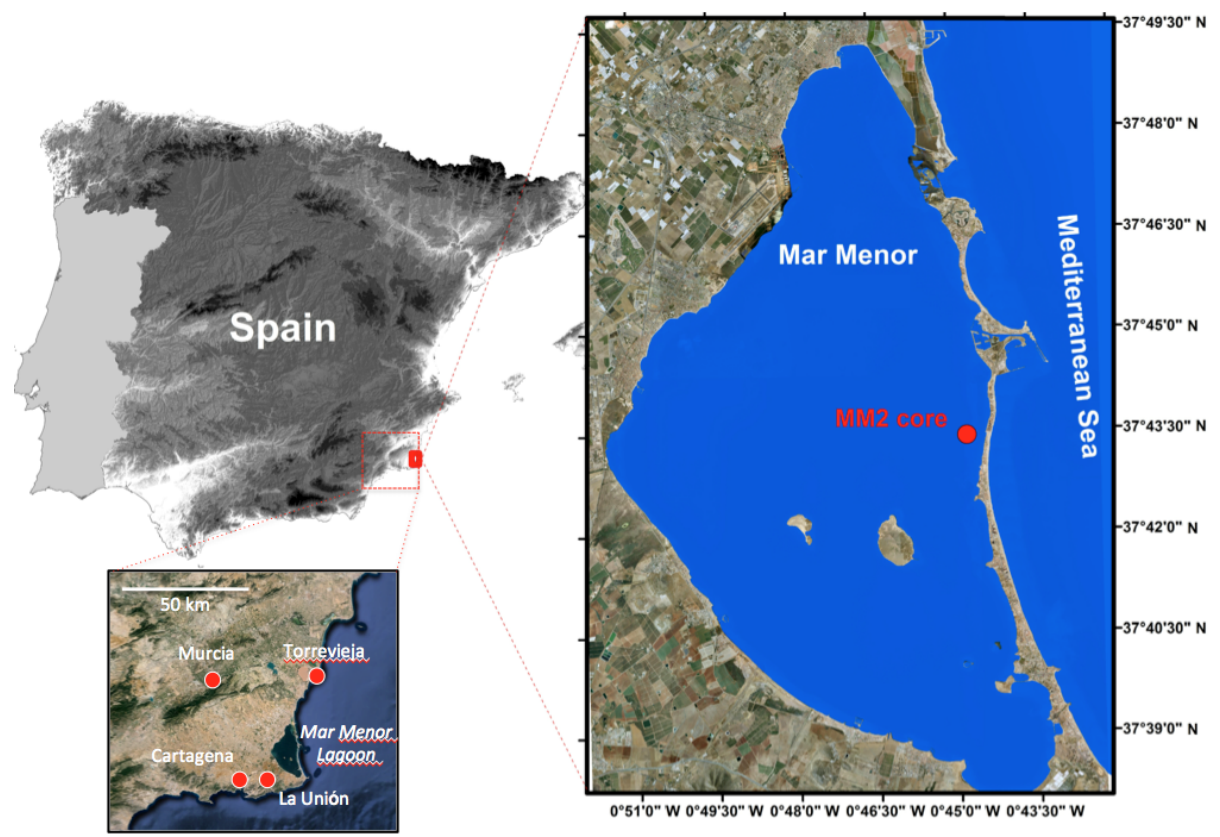

Figure 1. Map of the Mar Menor with localization of the core MM2.

trometry at the Géosciences Montpellier Laboratory (Montpellier, France). ${ }^{14} \mathrm{C}$ analyses were realized on mollusc shells at the Laboratoire de Mesure 14C (LMC14) with the ARTEMIS accelerator mass spectrometer (Accélérateur pour la Recherche en sciences de la Terre, Environnement, Muséologie Installé à Saclay) at the CEA institute at Saclay. These measurements were obtained from monospecific samples of Cerastoderma glaucum at each level. ${ }^{14} \mathrm{C}$ ages were corrected for reservoir age (see Sabatier et al., 2010, for method) and converted to calendar years using the computer program OxCal v4.2 (Bronk Ramsey, 2001, 2008) at 2 standard deviations (see Sect. 4.4).

\subsection{Spectral analyses}

Cyclic patterns in the Mar Menor lagoonal sequence were studied from spectral analyses by using two methods in order to reduce the possible biases of a single method (Desprat et al., 2003). We used the maximum entropy method (MEM) and the multi-taper method (MTM). The MEM selects the spectrum with the highest entropy, which represents the least biased estimate for the given information. This suggests that the MEM is maximally noncommittal regarding the unmeasured data (Harremoës and Topsoe, 2001). The spectrum obtained by this method shows an excellent frequency resolution with sharp spectral features (Berger et al., 1991; Dubar, 2006; Pardo-Iguzquiza and Rodriguez-Tovar, 2006). The MTM is a non-parametric method that (1) reduces the variance of spectral estimates by combining multiple orthogonal windows in the time domain before Fourier transforming and (2) provides a narrowband $F$ test useful for assess- ing the significance of periodic components (Thomson, 1982, 1990; Percival and Walden, 1993).

\section{Results}

\subsection{Core description}

Photo, X-ray images, X-ray fluorescence, and highresolution grain size analysis for MM2 indicate several thin, coarse-grained layers preserved within mud sediments. These coarse layers are constituted by a mixture of shell debris and siliciclastic sand and have basal boundaries easily identified by a change to coarser grain size and darker colour on X-ray images (Fig. 2a). Theses coarser grain size layers indicate "energetic" events, relative to the background sedimentation (i.e mud facies), and are probably linked to washover events (storm or tsunami).

\subsection{Sediment source}

The terrigenous fraction in the Mar Menor is mainly controlled by terrestrial and marine inputs. The core (MM2) was collected at $800 \mathrm{~m}$ from the sandy barrier and more than $8500 \mathrm{~m}$ from the different river mouths. At our study site, watercourses are the source of fine fraction dispersed in the lagoon and marine inputs are characterized by coarse sands. The lagoon barrier beach sand samples show a unimodal distribution, with a mean grain population ranging between 160 and $653 \mu \mathrm{m}$. The percentages of this grain population decrease from the sea to the lagoon in surface samples (Fig. 2b). The evolution with depth of this population displays eight 
(a)

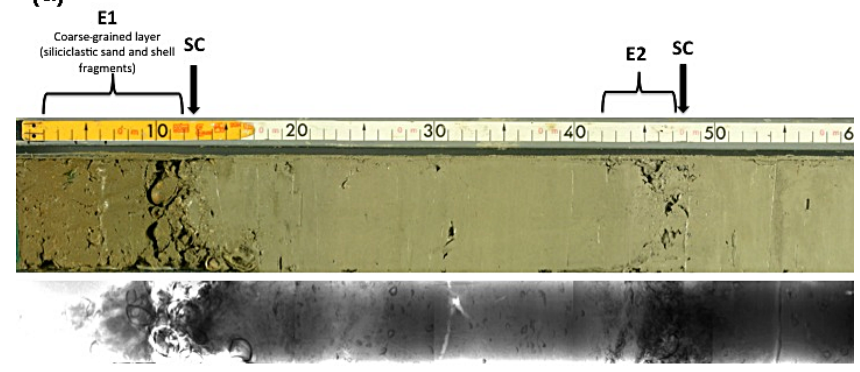

(b)
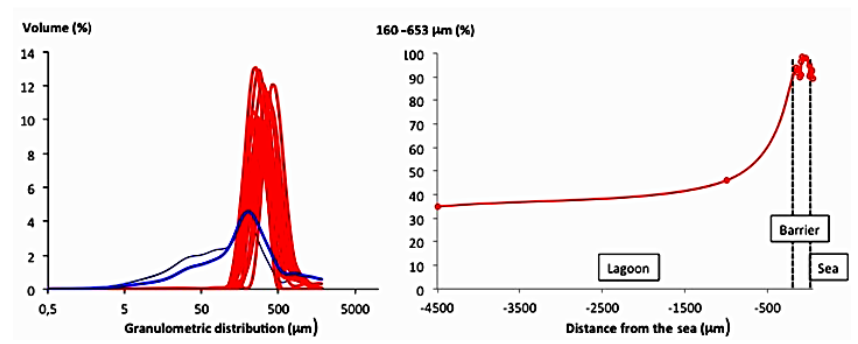

Figure 2. Panel (a): photography and X-ray of the core MM2 (0 and $60 \mathrm{~cm}$ ). Coarse-grained layers are a mixture of siliciclastic sand and shell fragments. These layers often have sharp contacts (SC) with the clay and silt sediments below. Panel (b): granulometric distribution of surface samples collected on an E-W transect from the sea and the barrier (red) to the lagoon (blue). Evolution of the 160$653 \mu \mathrm{m}$ population from the sea to the lagoon in surface samples.

main changes in the MM2 core, revealed by the grey bands in Fig. 3. The main peaks in coarse sands occur around 290, 255, 210, 170, 150, 60, 40, and $5 \mathrm{~cm}$ (Fig. 3).

Major chemical elements using the ITRAX core scanner provide high-resolution palaeoenvironmental information in a variety of sedimentary environments. In the present study we chose the ratio $\mathrm{Si} / \mathrm{Al}$ and $\mathrm{Zr} / \mathrm{Al}$, which better discriminate between the two source areas: marine vs. drainage basin (Dezileau et al., 2011; Sabatier et al., 2012; Raji et al., 2015). The high $\mathrm{Zr} / \mathrm{Al}$ ratio value is probably explained by the presence of heavy minerals (like zircon) from marine sand, and the high $\mathrm{Si} / \mathrm{Al}$ ratio is due to quartz minerals in marine sand. $\mathrm{Si} / \mathrm{Al}$ and $\mathrm{Zr} / \mathrm{Al}$ ratios have the same evolution with depth, especially in the first $3 \mathrm{~m}$ of the sediment core (Fig. 4, shaded bands).

A fundamental step in the core analysis is to establish criteria to correctly identify overwash layers. We systematically used grain size variation and geochemical signatures (i.e. $\mathrm{Si} / \mathrm{Al}$ and $\mathrm{Zr} / \mathrm{Al}$ ratios). As the background sedimentation shows a fine silt facies, we consider values higher than $20 \%$ of the $63 \mu \mathrm{m}$ fraction as outlining "high-energy" events (Fig. 3). Positive anomalies of the $\mathrm{Si} / \mathrm{Al}$ and $\mathrm{Zr} / \mathrm{Al}$ ratios, above 12 and 2.5 respectively (Fig. 4), indicate a higher relative contribution of marine sand. The marine origin of these high-energy events was also highlighted by mollusc iden-

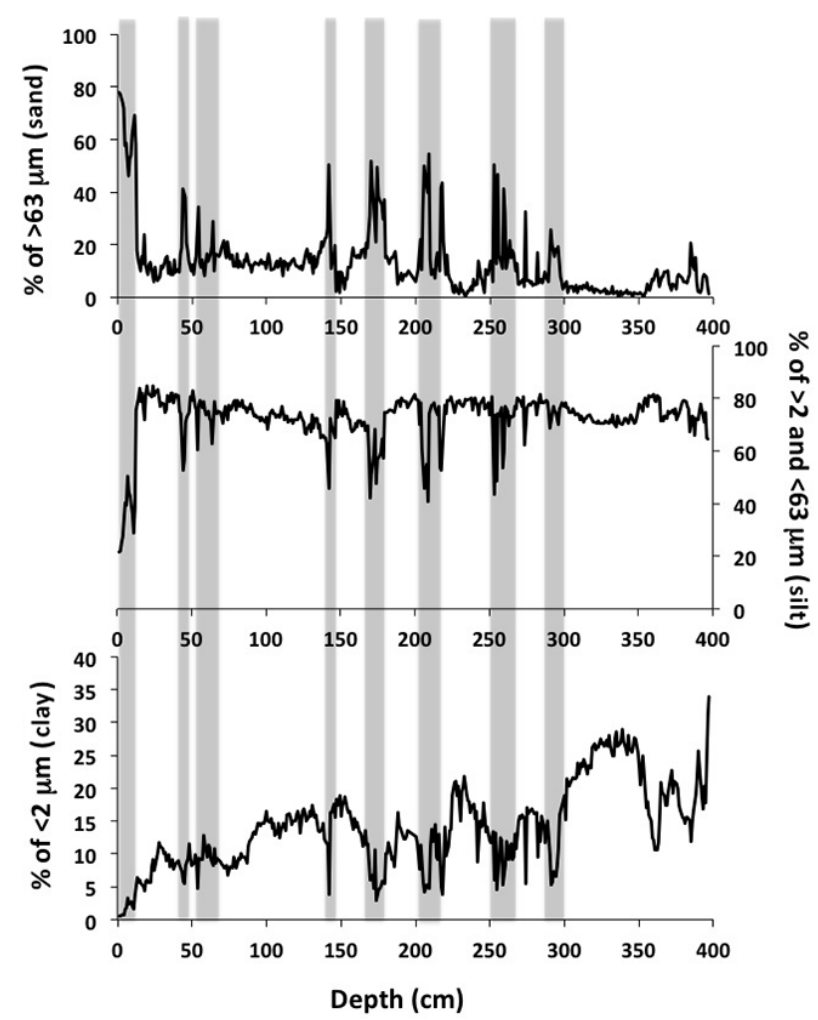

Figure 3. Grain size population from the Mar Menor MM2 record with clay $(<2 \mu \mathrm{m})$, silt $(>2$ and $<63 \mu \mathrm{m})$, and sand fraction $(>63 \mu \mathrm{m})$. Shaded areas mark the main variations of the sand fraction.

tification (Bittium reticulatum and Rissoa ventricosa) (see Sect. 4.3, Fig. 6).

\subsection{Faunal variations}

Macrofauna analyses are a good indicator of a lagoon palaeoisolation state. While total abundance and relative abundance of individuals of the different species are good indicators of environmental stress and lagoon productivity, species richness is a good indicator of marine influence because species develop in different ranges of salinity, temperature, and oxygenation and the colonization by marine species of the lagoon environments depends of the isolation degree and connectivity between both systems (Pérez-Ruzafa and Marcos, 1992, 2005). Figure 5 shows the variation in the number of species and total abundance (number of individuals in $100 \mathrm{~cm}^{3}$ ) along the studied time series. Taxon richness ranges between 0 , at depths higher than $365 \mathrm{~cm}$, and 18, reached at a $260 \mathrm{~cm}$ depth. The taxon-poor depths correspond to 302 $362 \mathrm{~cm}$, with a mean of 4.76 taxons, $72-78 \mathrm{~cm}$ with a mean of 5 taxons, and $30-36 \mathrm{~cm}$ with a mean of 5.7 taxons. The depths with the highest species richness are 192 to 266 and 81 to $186 \mathrm{~cm}$. These depths would correspond to a higher marine influence. Above $150 \mathrm{~cm}$, a progressive impoverishment 


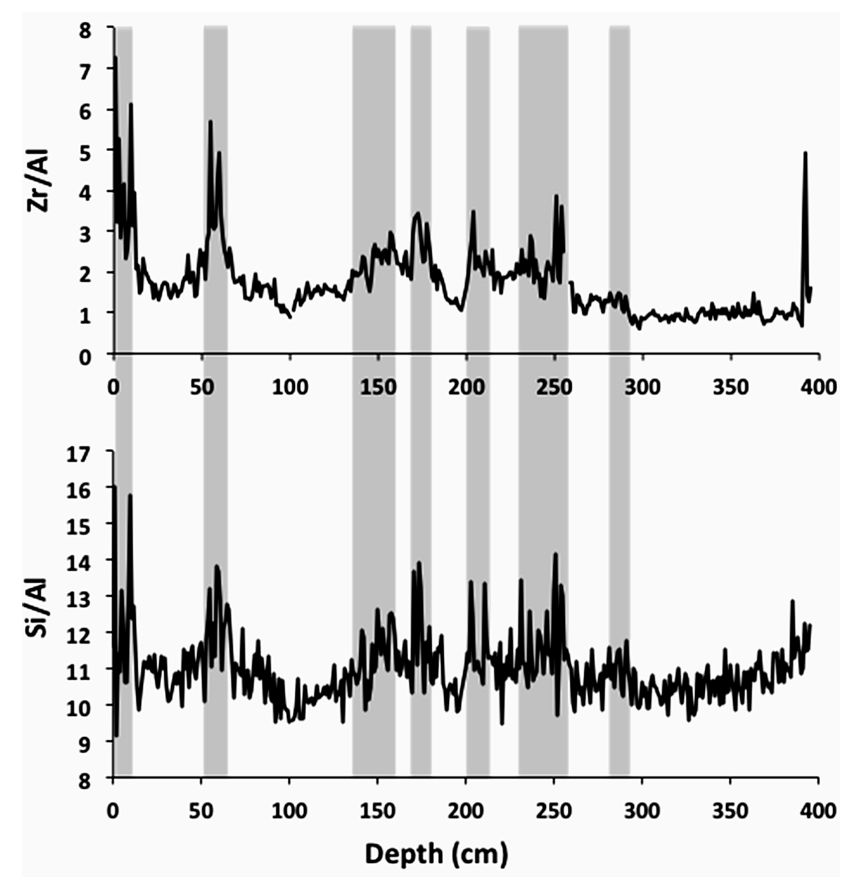

Figure 4. XRF records from the core MM2 with down-core variations of the ratios $\mathrm{Zr} / \mathrm{Al}$ and $\mathrm{Si} / \mathrm{Al}$. Shaded areas mark the main variations of $\mathrm{Zr} / \mathrm{Al}$ and $\mathrm{Si} / \mathrm{Al}$.

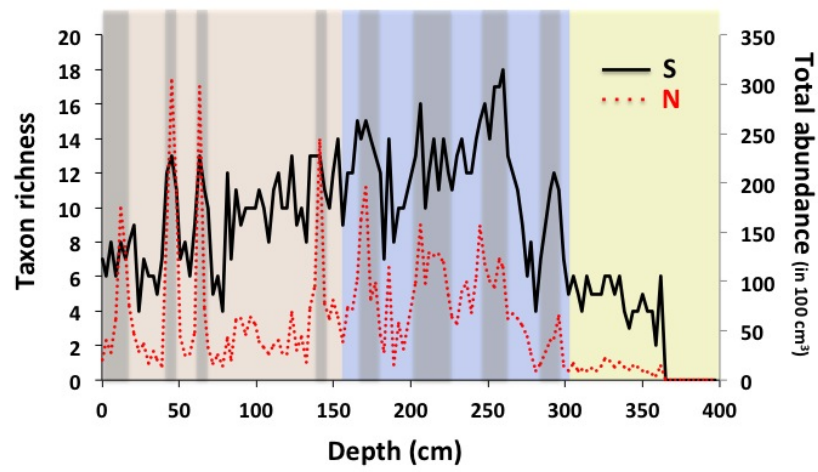

Figure 5. Taxon richness $(S)$ and total number of individuals $(N)$ with depth from core MM2. Macrofauna samples were taken at fixed volume $\left(100 \mathrm{~cm}^{3}\right)$. The different colour bands correspond to depths: azoic (yellow), under higher marine influence (blue), and under a progressive isolation of the Mar Menor from the Mediterranean Sea (brown). The grey bands correspond to occasional peaks in species richness, probably related to episodes in which the sandbar was ruptured.

in the number of species takes place, reflecting a progressive isolation of the Mar Menor from the Mediterranean Sea, with occasional peaks in species richness, probably related to episodes in which the sandbar was ruptured (Fig. 5).

The most frequent species, present in more than $50 \%$ of the samples, excluding the azoic depths, are Corbula gibba (Olivi, 1792) (92.4\%), Bittium reticulatum (da
Costa, 1778) (84.9\%), Tellina sp. (78.9\%), Pusillina (=Rissoa) lineolata (Michaud, 1830) $(78.2 \%)$, Acanthocardia paucicostata (G. B. Sowerby II, 1834) (77.3\%), Cerastoderma glaucum (Bruguière, 1789) (71.4\%), Anthalis sp. (63.9\%), Abra sp. (74.8\%), Loripes lacteus (Linnaeus, 1758) (61.3\%), and Philine aperta (Linnaeus, 1767) $(59.7 \%)$. Hydrobiidae sp. appear in $47.9 \%$ of the samples but are restricted to the upper $150 \mathrm{~cm}$, constituting $61.5 \%$ of the assemblage at $15 \mathrm{~cm}$ depth section. This species is a typical lagoon inhabitant. Conus ventricosus (Gmelin, 1791) appears only in $13.5 \%$ of the samples, from between 162 and $293 \mathrm{~cm}$ depth, and reaches a dominance of up to $7 \%$ in the assemblage. Together with the presence of abundant sea urchin spines, it characterizes typical marine conditions.

The data in Fig. 6 show a main change in mollusc population at around $150-130 \mathrm{~cm}$ characterized by an increase in the most typical lagoonal species, Hydrobia acuta, whereas the abundance of species with a marine affinity like Pusillina (= Rissoa) lineolata and Conus ventricosus decrease (Fig. 6). This main change in mollusc population also reveals a major palaeoenvironmental change around $150 \mathrm{~cm}$; this faunal variation is probably due to a change in environmental context from a lagoonal environment, with a marine influence to a more isolated environment.

\subsection{Age model}

The chronology of core MM2 has been established for the last 6500 years using ${ }^{137} \mathrm{Cs},{ }^{210} \mathrm{~Pb}$, and (AMS) ${ }^{14} \mathrm{C}$ dates on monospecific shell samples, geochemical analysis of mining-contaminated lagoonal sediments, and palaeomagnetism (Dezileau et al., 2016a). The radiocarbon age of lagoonal and marine organisms is usually older than the atmospheric ${ }^{14} \mathrm{C}$ age and has to be corrected by the substraction of the "reservoir age" (Siani et al., 2001; Reimer and McCormac, 2002; Zoppi et al., 2001; Sabatier et al., 2010; Dezileau et al., 2016b). We evaluated the modern reservoir ${ }^{14} \mathrm{C}$ age by comparing an age derived from ${ }^{137} \mathrm{Cs}$ and ${ }^{210} \mathrm{~Pb}$ data and from geochemical analysis of mining-contaminated lagoonal sediments with an $\mathrm{AMS}{ }^{14} \mathrm{C}$ age of a pre-bomb mollusc shell (see Sabatier et al., 2010, for method). The reservoir age $(R(t))$ with a value of $1003 \pm 62{ }^{14} \mathrm{C}$ yr is 600 years higher than the mean marine reservoir age (around 400 years) and may be explained by isolation of the lagoon from the Mediterranean Sea. This high reservoir age value is similar to other estimates in different Mediterranean lagoons (Zoppi et al., 2001; Sabatier et al., 2010).

${ }^{14} \mathrm{C}$ ages were also obtained for a series of Holocene mollusc shells sampled at different depths of the $\sim 2 \mathrm{~m}$ long core MM2 (Fig. 7, Dezileau et al., 2016a). Comparing palaeomagnetic ages and ${ }^{14} \mathrm{C}$ ages versus depth, we show that the reservoir age has changed in the past and was lower (505 years) than the modern value (1003 years; Dezileau et al., 2016a). This change was also observed in another Mediterranean lagoon (Sabatier et al., 2010). In the Mar Menor, the linear sed- 


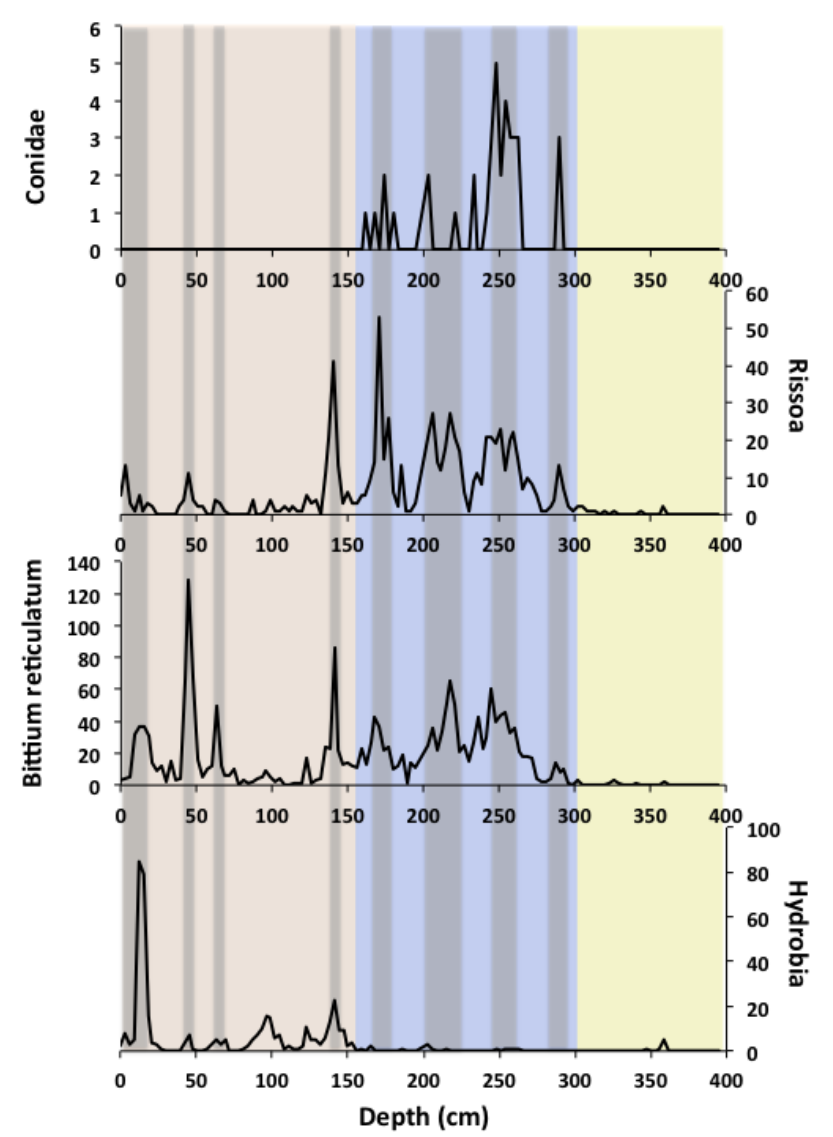

Figure 6. Evolution of the abundance in mollusc population (number of individuals in $100 \mathrm{~cm}^{3}$ ) with depth: lagoonal species (Hydrobia acuta), typical marine species (Conus ventricosus: Conidae), marine influence (Bittium reticulatum and Pusillina lineolata: Rissoa).

imentation rate (LSR) obtained for the core MM2 suggests a low mean accumulation rate of $0.6 \mathrm{~mm} \mathrm{yr}^{-1}$, from the base to the top of the core.

\section{Discussion}

\subsection{Site sensitivity to overwash deposits}

Site sensitivity to overwash deposits may result from different factors such as barrier elevation, sediment supply, inlet, and a change in sea level (Donnelly et al., 2004; Scileppi and Donnelly, 2007; Dezileau et al., 2011). An increase in sea level induces a shift of the barrier landward. Therefore, an increase in sand layers in a sediment core may be due to a sea level change. In the Mediterranean Sea, the sea level has remained more or less constant during the last 5000 years (<2 m, Pirazzoli, 1991; Lambeck and Bard, 2000). Before this period, a significant change in sea level occurred. During the first phase of lagoonal sediment deposit (between 6500 and $5000 \mathrm{yr}$ cal BP), the number of sand layers is low.

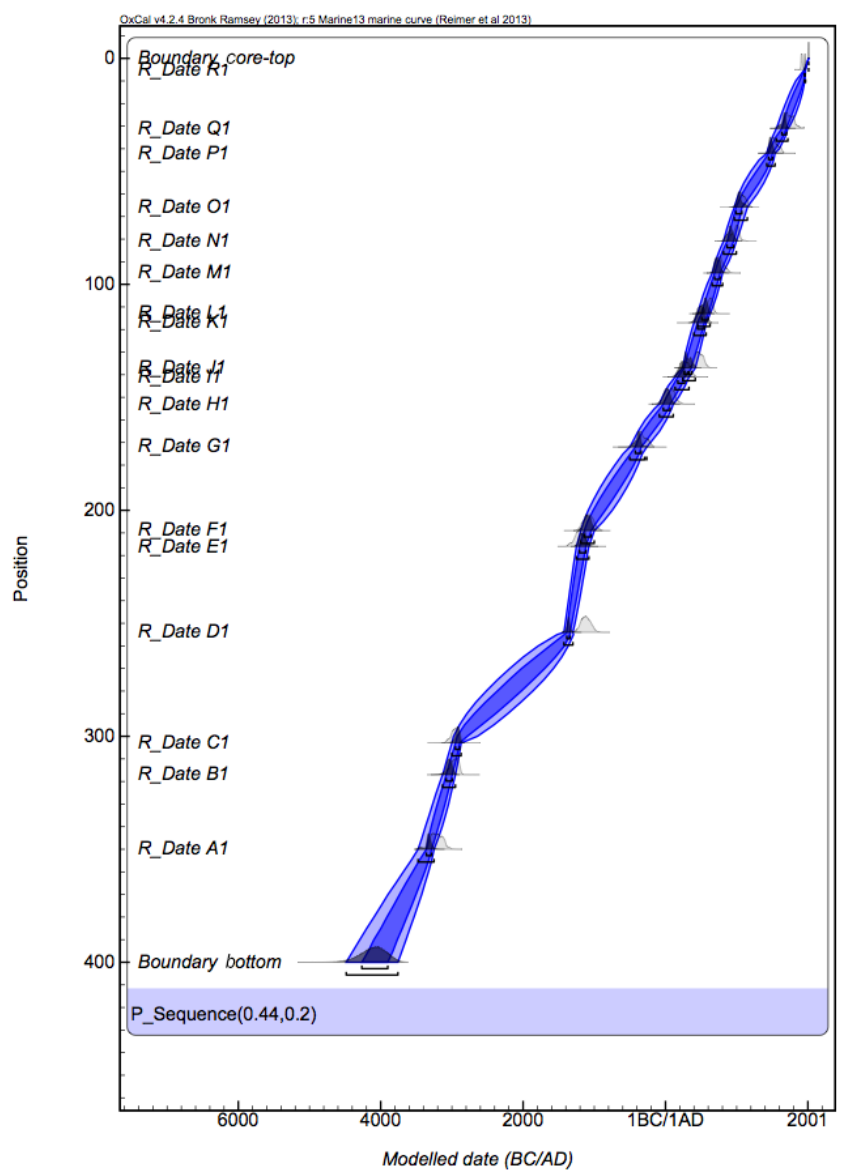

Figure 7. Age vs. depth for the core MM2. The age model was calculated using $\mathrm{OxCal} 4$ with $17{ }^{14} \mathrm{C}$ dates.

The sandy barrier was probably at more than $1 \mathrm{~km}$ from the present position, and this may probably explain why sand layers are not observed. The strong increase in coarse-grain layer frequency after ca. $5400 \mathrm{yr}$ cal BP can be explained by a migration of the barrier up to a position which is not far away from the present position.

Fauna content reveals a major palaeoenvironmental change around $150 \mathrm{~cm}$ (i.e. $2400 \mathrm{yrcal} \mathrm{BP}$; Fig. 6). Such change is probably due to a shift from a "leaky lagoon" to a "restricted and choked lagoon" environment, sensu Kjerfve (1994). Thus, after this date (i.e. $2400 \mathrm{yrcal} \mathrm{BP}$ ) the barrier was continuous with inlets sometimes forming in response to intense overwash events. To conclude, since $2400 \mathrm{yrcal} \mathrm{BP}$, the lagoon has been isolated from the sea. During this period the general morphology of the lagoon and the barrier have not changed drastically. Between 5400 and $2400 \mathrm{yr}$ cal BP, the lagoon was less isolated from the Mediterranean Sea, as is typical for a leaky lagoon environment. During this period, fine sediments were accumulated. The lagoon experienced quiescent sedimentation probably protected by a more or less continuous sandy barrier. The presence of sand layers may be interpreted as a result of intense over- 
wash events. Between 6500 and $5400 \mathrm{yr} \mathrm{BP}$, the morphology of the lagoon and the barrier is different. The position of the sandy barrier was far away from the present position. In this case, the number and the intensity of surge events recorded are not comparable to the upper part of the core (Figs. 3 and 8). During this period, the lack of sand layers does not mean no surge events but simply that they are not recorded.

The record of palaeostorm events can be complicated by different factors; however, the clay or silt sediment types appearing throughout the record show that this area was experiencing quiescent sedimentation, indicating that the site was protected behind a sandy barrier during that time. Moreover, in order to control localized sensitivity changes, it will be necessary in the future to employ a multiple-site approach, as extreme storms or tsunamis in all of this area would likely result in surges and waves of sufficient height to overtop the barrier across wide stretches of the coast and not only in a localized area.

\subsection{Storms or tsunamis?}

The $\mathrm{Zr} / \mathrm{Al}$ and $\mathrm{Si} / \mathrm{Al}$ ratios of sandy layers are above 12 and 2.5 respectively (Fig. 8), indicating a higher relative contribution of marine sand. The marine origin of these high-energy events was also highlighted through mollusc identification (Bittium recticulatum and Rissoa ventricosa, Fig. 8). This multiproxy approach suggests the occurrence of eight periods of increased overwash events, reflecting perturbations of coastal hydrodynamics due to palaeostorm or palaeotsunami events (grey band in Fig. 8).

Both tsunamis and storms induce coastal flooding. It is difficult to discriminate between storm and tsunami deposits (Kortekaas and Dawson, 2007; Morton et al., 2007; Engel and Brückner, 2011). The coarse-grained layers observed in the core MM2 could be a signature of tsunamis or storms. Records of historic and contemporary coastal hazards (storms and tsunamis) may help us to determine which historical events left a sedimentological signature in the Mar Menor.

In textual archives, extreme storm events were described due to the strong economic and societal impact of these events (Seisdedos et al., 2013). In the last 200 years, 27 storms affected the coast of Murcia. Among all of these storms, some seem to have been more catastrophic than others. The storm of 1 November 1869 caused the wreckage of a numerous ships in Torrevieja harbour. Between Isla Grosa and San Pedro del Pinatar more than 35 ships sank. In the Mar Menor, 50 fishing boats were destroyed. Wave heights associated with this storm were estimated to have been higher than $8 \mathrm{~m}$ off the La Manga sandbar. This severe storm also affected the cities of La Unión and Cartagena, destroying houses and paralysing the cities for many days. From the hydrological and ecological point of view, the 1869 storm led to drastic and persistent changes in the salinity of the lagoon and to the colonization of new species of marine ori-

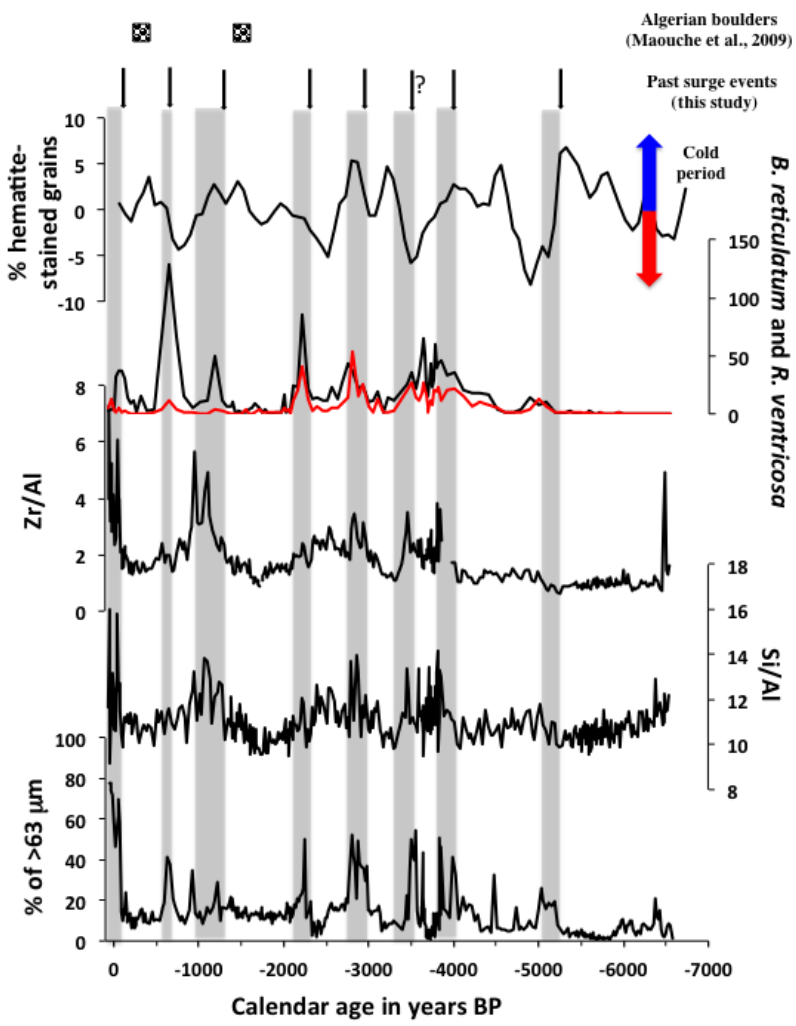

Figure 8. Core MM2 with from bottom to top: grain size (sand fraction); $\mathrm{Si} / \mathrm{Al}$ and $\mathrm{Zr} / \mathrm{Al} \mathrm{XRF}$ ratio; number of $B$. reticulatum (black line) and $R$. ventricosa (red line); percentage of hematitestained grains (Bond et al., 1997, 2001), ages of Algerian boulders (Maouche et al., 2009). Grey bands are the past surge events.

gin (Navarro, 1927), affecting also the fisheries in the lagoon (Pérez-Ruzafa et al., 1991). There are historical references to some other storms that led to the breaking of the sandbar in the Mar Menor (in 1526, 1676, 1687, 1690, 1692, 1694, 1706, 1762, 1765, 1787, and 1795; Jiménez de Gregorio, 1957; Pérez-Ruzafa et al., 1987), although there is no information about their magnitude, the extent and exact location of the breaks, and their impact on the lagoon environment. Some ups and downs in the number of species observed in Fig. 5 could be related to these events, but an extensive and detailed study would be required to understand the relationship between the frequency, duration, and intensity of the storms and the spatial and temporal scales of their effects and their impact on the fossil record.

Different tsunamis occurred on the Spanish coasts, they are more catastrophic and intense on the Atlantic than on the Mediterranean side (Álvarez-Gómez et al., 2011). In the western part of the Mediterranean area, there are historical disastrous tsunami events recorded. In northern Algeria, in addition to the 2003 tsunami, the first well-documented event is the tsunami in the Jijel area associated with the seismic event of August 1856, which was also recorded in the 
(a)

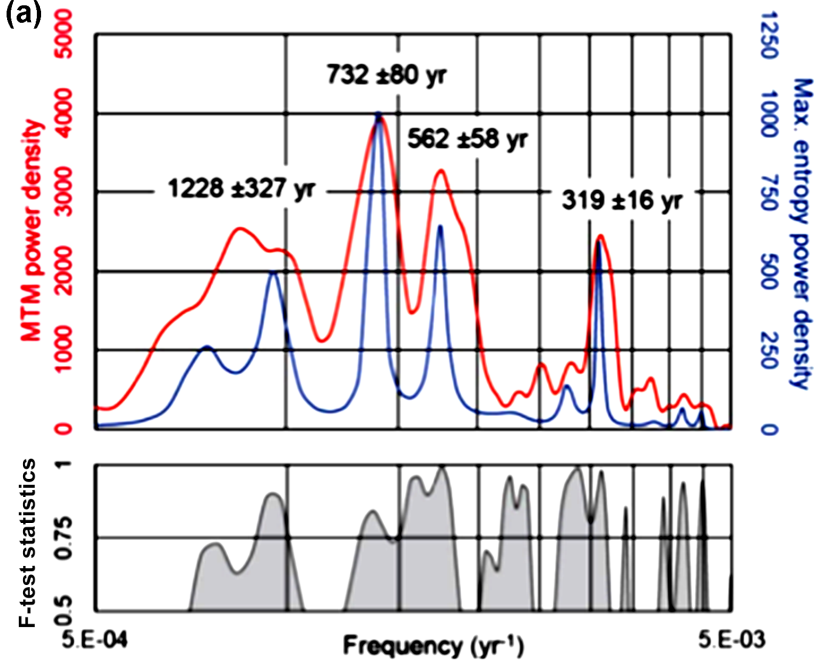

(b)

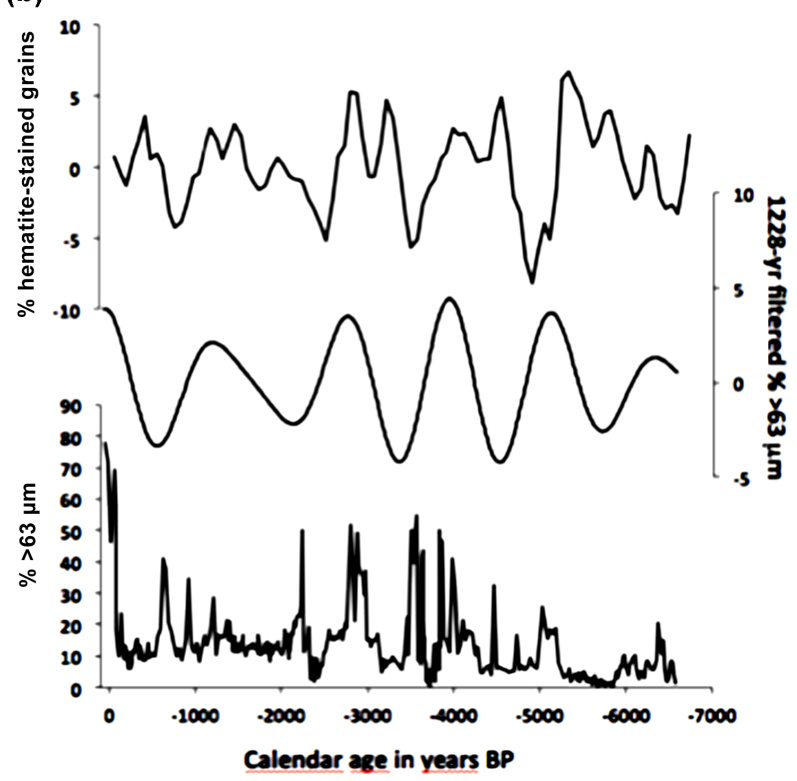

Figure 9. Time series analysis from the Mar Menor MM2 record. Panel (a): spectral analyses of the percentage of sand with AnalySeries v.2.0.8 (Paillard et al., 1996) by using the multi-taper method (linear trend removed; width.ndata product: 1.3; number of windows: 2) and the maximum entropy method (linear trend removed; percentage of series: 40, number of lags: 133). Panel (b): comparison between the percentage of hematite-stained grains (Bond et al., 1997, 2001), the Gaussian filter on the percentage of sand for the 1228-year period (frequency: 0.0008; bandwidth: 0.0002) and the sand fraction of the core MM2.

Balearic Islands (Maouche et al., 2009). In the Alboran Sea area some reports mention tsunamis that affected the African and Spanish coasts in 1790, 1804, and 1522 (IGN, 2009). For an earthquake with a magnitude of 6.8 (2003 Boumerdes earthquake) with its epicentre calculated at $15 \mathrm{~km}$ offshore of Zemmouri, Wang and Liu (2005) show that the tsunami phenomenon is regional in character using a numerical sim- ulation. The tsunami propagating from the Algerian coast to Murcia Province has a lesser amplitude and the tsunami wave height is low $(<25 \mathrm{~cm})$. The Boumerdes-Zemmouri tsunami did not cause any damage in the province of Murcia and the La Manga sandbar. Álvarez-Gómez et al. (2011) identified the hazardous sources and the areas where the impact of tsunamis is greater from numerical simulations. From a set of 22 seismic tsunamigenic sources, the maximum wave elevation was estimated between 0.5 and $1 \mathrm{~m}$ along the southeastern Spanish coast. All these historical events have been classified as a magnitude between 1 and 3 on the Tsunami Intensity Scale (where 6 is the maximum intensity; Maramai et al., 2014). Since these different historical events have a magnitude equal to or lower than the Boumerdes-Zemmouri tsunami (3 on the Tsunami Intensity Scale) and since this event did not affect significantly La Manga sandbar and the Province of Murcia, considering the available data, historical tsunami events do not seem to have been associated with the different sand layers in the Mar Menor in the last 500 years. From the Catálogo de Tsunamis en las Costas Españolas, no tsunamis are recorded along the south-eastern coast of Spain from -218 BC to AD 1756. No information on the existence of tsunamis is recorded over longer periods of time. However, more than 100 boulders were identified along the coastal zone of Algiers, and Maouche et al. (2009) suggested that the deposition of the biggest boulders could be attributed to tsunami events. The radiocarbon results highlight two groups of boulders dated to around AD 419 and 1700 . Although no historical accounts report these events, tsunami events are extremely rare and mainly of a low magnitude and cannot be the origin of the different sand layers in the Mar Menor.

To determine which historical events may lead to sandy layers, we compared our high-resolution record of past extreme sea events from the core MM2 to the catalogue of historical storm and tsunami events in the area. The first coarse-grained event layer has been dated to $80 \mathrm{cal} \mathrm{BP}$ (i.e. $1880 \mathrm{AD} \pm 30$ years). This sandy deposit could be associated with the storm of 1 November 1869, recorded in many city archives between Cartagena and Torrevieja and in the Mar Menor and considered the most catastrophic storm event in the Province of Murcia in the last 200 years. In the core MM2, no sand layers are consistent with the Algerian tsunamis dated to around 419 and $1700 \mathrm{AD}$ (Fig. 8). There is evidence that this sand layer is compatible with large storm waves.

\subsection{Storm activity in the context of past climatic changes}

Based on our ${ }^{14} \mathrm{C}$ age model, marine coarse-grained event layers occurred around 5250, 4000, 3600, 3010, 2300, 1350, 650 , and $80 \mathrm{yrcal} \mathrm{BP}$. Except for one period dated to 3600 years cal BP, the seven other periods of most frequent surge events in the Mar Menor seem to coincide with the coldest periods in Europe during the late Holocene, taking into ac- 
count chronological uncertainty (Fig. 8; Bond et al., 2001). A spectral analysis was performed on the ca. $6.5 \mathrm{kyr}$ time series of the sand percentage from the MM2 sequence. The results show four major frequencies with high spectral power densities and significant $F$ test values at ca. $8 \times 10^{-4}, 1.4 \times 10^{-3}$, $1.8 \times 10^{-3}$, and $3.1 \times 10^{-3}$ years $^{-1}$ (Fig. 9a). Considering the full width at half maximum (FWHM) of these peaks on the MTM spectrum, this yields respective periodicities of $1228 \pm 327,732 \pm 80,562 \pm 58$, and $319 \pm 16$ years for the MM2 sand percentage proxy. Multi-centennial to millennial timescale climate variabilities similar to these periodicities have been reported in the literature for the Holocene (Bond et al., 1997, 2001; Langdon et al., 2003; Debret et al., 2007, 2009; Wanner et al., 2011; Kravchinsky et al., 2013; Soon et al., 2014). Amongst the well-known proxies that have revealed a millennial-scale climate variability during the Holocene, the ice-rafted debris (IRD) indices in the North Atlantic developed by Bond et al. (1997, 2001) present a cyclicity of $1470 \pm 500$ years, which matches the $1228 \pm 327$-year periodicity evidenced in the Mar Menor, considering the respective uncertainties in the periodicities. When filtering the raw data of the Mar Menor sand percentage recorded with a Gaussian filter with a frequency of $8 \times 10^{-4}$ years $^{-1}$ (1228 years), six cycles appear with a noteworthy enhancement of the cyclic amplitude after 5500 cal yr BP (Fig. 9b). The five ascending phases occurring on the 1228-year filtered curve at ca. 5715/5115, 4525/3945, 3365/2775, 2145/1215, and $575 /-35$ cal yr BP approximate the high storm activity periods evidenced in the French Mediterranean lagoon of Pierre-Blanche during the last 7000 years (Sabatier et al., 2012).

The origin of the stormy periods evidenced by the spectral analysis in the Mar Menor can be discussed in the light of previous works mentioning analogous climate variabilities during the Holocene. Bond et al. $(1997,2001)$ associated the $1470 \pm 500$-year IRD cycle with solar forcing, amplified by a change in North Atlantic Deep Water production. Langdon et al. (2003) found a sub-millennial climate oscillation in Scotland possibly related to the North Atlantic thermohaline circulation (THC). Moreover, Debret et al. (2007, 2009) showed a cyclicity of 1500 years since the mid-Holocene, probably linked to an internal forcing due to the THC.

Concerning the multi-centennial periodicities, Soon et al. (2014) used global proxies to evidence a 500-year fundamental solar mode and to identify intermediate derived cycles at 700 and 300 years, which could be rectified responses of the Atlantic THC to external solar modulation and pacing. Kravchinsky et al. (2013) also found a 500-year climate cycle in southern Siberia presumed to be derived from increased solar insolation and possibly amplified by other mechanisms. Some authors found a relationship between the ca. 700-year period and the monsoonal or ITCZ regimes in equatorial Africa (Russell et al., 2003; Russell and Johnson, 2005), southern Asian (Staubwasser et al., 2003), and the eastern Arabian Sea (Sarkar et al., 2000), while other au- thors suggested that the ca. 700-800-year period could be a subharmonic mode derived from the fundamental 1500year cycle of the THC (Von Rad et al., 1999; Wang et al., 1999). Moreover, Rimbu et al. (2004) mentioned a 700-year variability in sea-surface temperature (SST) records in the tropical and North Atlantic. Hence, our results seem to indicate that the late Holocene multi-centennial variability of the cyclogenesis in the western Mediterranean was regulated by both external (solar) and internal (THC and ITCZ) forcings. Further investigations of additional sequences and highresolution coastal imagery will be required to reliably determine the origin of these multi-centennial periods in the Mediterranean area.

\section{Conclusion}

This study provides a 6500-year high-resolution record of past overwash events using a multi-proxy approach of a sediment core from the Mar Menor in Spain in the western Mediterranean Sea. Eight sandy layers are preserved in the core and seem to be associated with periods of increased extreme sea events. The results indicate little likelihood of a tsunami origin for these coarse-grained layers, although historical tsunami events are recorded in this area. These surge events seem to coincide with climatic cold periods in Europe during the late Holocene, suggesting a control by a climatic mechanism for periods of increased storm activity. From the available data, we have identified seven periods of high storm activity at around 5250, 4000, 3600, 3010, 2300, 1350,650 , and $80 \mathrm{yr}$ cal BP. Except for one period, dated to $3600 \mathrm{yr}$ cal BP, the seven other periods of most frequent surge events in the Mar Menor seem to coincide with the coldest periods in Europe during the late Holocene, taking into account chronological uncertainty. Spectral analyses performed on the sand percentage revealed four major periodicities of $1228 \pm 327,732 \pm 80,562 \pm 58$, and $319 \pm 16$ years. The origin of the stormy periods evidenced by the spectral analysis in the Mar Menor can be discussed in the light of previous works mentioning analogous climate variabilities during the Holocene. Our results seem to indicate that the late Holocene multi-centennial variability of the cyclogenesis in western Mediterranean was steered by both external (solar) and internal (THC and ITCZ) forcings. However, further investigations, such as additional coring and high-resolution coastal imagery, are needed to better constrain the main cause of these multiple events.

Acknowledgements. The authors would like to thank all participants of the coring expedition, particularly E. Regnier (Technician, LSCE - IPSL, Paris) for his collaboration in the various stages of this study. This study is funded by the MISTRALS PALEOMEX project. We thank the Laboratoire de Mesure ${ }^{14} \mathrm{C}$ (LMC14) ARTEMIS at the CEA Institute at Saclay (French Atomic Energy Commission) for the ${ }^{14} \mathrm{C}$ analyses. This article benefitted from constructive reviews by Stella Kortekaas and Suzanne Leroy. 
Edited by: M.-F. Loutre

\section{References}

Álvarez-Gómez, J. A., Aniel-Quiroga, 1., González, M., and Otero, L.: Tsunami hazard at the Western Mediterranean Spanish coast from seismic sources, Nat. Hazards Earth Syst. Sci., 11, 227240, doi:10.5194/nhess-11-227-2011, 2011.

Berger, A., Melice, J.-L., and Hinnov, L.: A strategy for frequency spectra of Quaternary climate records, Clim. Dynam., 5, 227240, 1991.

Bond, G., Showers, W., Cheseby, M., Lotti, R., Almasi, P., DeMenocal, P., Priore, P., Cullen, H., Hajdas, I., and Bonani, G.: A pervasive millennial-scale cycle in North Atlantic Holocene and Glacial climates, Science, 278, 1257-1266, 1997.

Bond, G., Kromer, B., Beer, J., Muscheler, R., Evans, M. N., Showers, W., Hoffmann, S., Lotti-Bond, R., Hajdas, I., and Bonani, G.: Persistent solar influence on North Atlantic climate during the Holocene, Science, 294, 2130-2136, 2001.

Bronk Ramsey, C.: Development of the Radiocarbon calibration program OxCal, Radiocarbon, 43, 355-363, 2001.

Bronk Ramsey, C.: Deposition models for chronological records, Quaternary Sci. Rev., 27, 42-60, 2008.

Debret, M., Bout-Roumazeilles, V., Grousset, F., Desmet, M., McManus, J. F., Massei, N., Sebag, D., Petit, J.-R., Copard, Y., and Trentesaux, A.: The origin of the 1500-year climate cycles in Holocene North-Atlantic records, Clim. Past, 3, 569-575, doi:10.5194/cp-3-569-2007, 2007.

Debret, M., Sebag, D., Crosta, X., Massei, N., Petit, J.-R., Chapron, E., and Bout-Roumazeilles, V.: Evidence from wavelet analysis for a mid-Holocene transition in global climate forcing, Quaternary Sci. Rev., 28, 2675-2688, 2009.

Desprat, S., Sanchez-Goni, M. F., and Loutre, M.-F.: Revealing climatic variability of the last three millennia in northwestern Iberia using pollen influx data, Earth Planet. Sc. Lett., 213, 63-78, 2003.

Dezileau, L., Sabatier, P., Blanchemanche, P., Joly, B., Swingedouw, D., Cassou, C., Castaings, J., Martinez, P., and Von Grafenstein, U.: Intense storm activity during the Little Ice Age on the French Mediterranean coast, Palaeogeogr. Palaeocl., 299, 289-297, 2011.

Dezileau, L., Pérez-Ruzafa, A., Camps, P., Blanchemanche P., and Grafenstein, U.: Holocene variations of radiocarbon reservoir ages in the Mar Menor lagoon system, Radiocarbon, in preparation, $2016 \mathrm{a}$.

Dezileau, L., Lehu, R., Lallemand, S., Hsu, S.-K., Babonneau, N., Ratzov, G., Lin, A. T., and Dominguez, S.: Historical reconstruction of submarine eartquakes using $210 \mathrm{~Pb}, 137 \mathrm{Cs}$ and $241 \mathrm{Am}$ turbidite chronology and radiocarbon reservoir age estimation off East Taiwan, Radiocarbon, 58, 25-36, doi:10.1017/RDC.2015.3, 2006a.,

Donnelly, J. P., Webb III, T., Murnane, R., and Liu, K.: Backbarrier sedimentary records of intense hurricane landfalls in the northeastern United States, Hurricanes and Typhoons: Past, Present, and Future, 55, 58-95, 2004.

Dubar, M.: Approche climatique de la période romaine dans l'est du Var: recherche et analyse des composantes périodiques sur un concrétionnement centennal (Ier-IIe siècle apr. J.-C.) de l'aqueduc de Fréjus, ArchéoSciences, 30, 163-171, 2006.

Engel, M. and Brückner, H.: The identification of palaeo-tsunami deposits - a major challenge in coastal sedimentary research, Dynamische Küsten - Grundlagen, Zusammenhänge und Auswirkungen im Spiegel angewandter Küstenforschung, Proceedings of the 28th Annual Meeting of the German Working Group on Geography of Oceans and Coasts, 2011, 22-25, 2011.

Gaertner, M. A., Jacob, D., Gil, V., Domínguez, M., Padorno, E., Sánchez, E., and Castro, M.: Tropical cyclones over the Mediterranean Sea in climate change simulations, Geophys. Res. Lett., 34, 1-5, doi:10.1029/2007GL029977, 2007.

Harremoës, P. and Topsoe, F.: Maximum entropy fundamentals, Entropy, 3, 191-226, 2001.

IGN: Catalogo de Tsunamis en las Costas Espanolas, Instituto Geografico Nacional, https://www.ign.es/ign/resourcessismologia/ tsunami/catalogoTsunamis.pdf (last access: 14 May 2016), 2009.

Jimenez de Gregorio, F.: El Municipio de San Javier en la historia del Mar Menor y su ribera, Ayuntamiento de San Javier, Murcia, 1957.

Jiménez-Martínez, J., Candela, L., García-Aróstegui, J. L., and Aragón, R.: A 3D geological model of Campo de Cartagena, SE Spain: hydrogeological implications, Geol. Acta, 10, 49-62, 2012.

Kelletat, D. and Schellmann, G.: Tsunamis on Cyprus: field evidences and 14C dating results, Z. Geomorphol., 46, 19-34, 2002.

Kjerfve, B.: Coastal lagoons, in: Coastal lagoon processes, Elsev. Oceanogr. Ser., 60, 1-8, 1994.

Kortekaas, S. and Dawson, A.: Distinguishing tsunami and storm deposits: an example from Martinhal, SW Portugal, Sediment. Geol., 200, 208-221, 2007.

Kravchinsky, V. A., Langereis, C. G., Walker, S. D., Dlusskiy, K. G., and White, D.: Discovery of Holocene millennial climate cycles in the Asian continental interior: Has the sun been governing the continental climate?, Global Planet. Change, 110, 386-396, 2013.

Lambeck, K. and Bard, E.: Sea-level change along the French Mediterranean coast for the past 30000 years, Earth Planet. Sc. Lett., 175, 203-222, 2000.

Langdon, P. G., Barber, K. E., and Hugues, P. D. M.: A 7500year peat-based palaeoclimatic reconstruction and evidence for an 1100-year cyclicity in bog surface wetness from Temple Hill Moss, Pentland Hills, southeast Scotland, Quaternary Sci. Rev., 22, 259-274, 2003.

Lionello, P., Bhend, J., Buzzi, A., Della-Marta, P. M., Krichak, S., Jansá, A., Maheras, P., Sanna, A., Trigo, I. F., and Trigo, R.: Cyclones in the Mediterranean region: climatology and effects on the environment, in Mediterranean Climate Variability, in: Mediterranean Climate Variability, Developments in Earth and Environmental Sciences, edited by: Lionello, P., MalanotteRizzoli, P., and Boscolo, R., 4, Elsevier, Amsterdam, the Netherlands, 324-372, 2006.

Maouche, S., Morhange, C., and Meghraoui, M.: Large boulder accumulation on the Algerian coast evidence tsunami events in the western Mediterranean, Mar. Geol., 262, 96-104, 2009.

Maramai, A., Brizuela, B., and Graziani, L.: The EuroMediterranean Tsunami Catalogue, Ann. Geophys., 57, S0435, doi:10.4401/ag-6437, 2014. 
Morhange, C., Marriner, N., and Pirazzoli, P. A.: Evidence of LateHolocene Tsunami Events in Lebanon, Z. Geomorphol. Supp., 146, 81-95, 2006.

Morton, R. A., Gelfenbaum, G., and Jaffe, B. E.: Physical criteria for distinguishing sandy tsunami and storm deposits using modern examples, Sediment. Geol., 200, 184-207, 2007.

Navarro, F.: Observaciones sobre el Mar Menor (Murcia). Notas y resúmenes del Instituto Español de Oceanografía, Ser. II, 16, 163, 1927.

Paillard, D., Labeyrie, L., and Yiou, P.: Macintosh program performs time-series analysis, EOS Transactions AGU, 77, 379379, 1996.

Pardo-Iguzquiza, E. and Rodriguez-Tovar, F. J.: Maximum entropy spectral analysis of climatic time series revisited: Assessing the statistical significance of estimated spectral peaks, J. Geophys. Res., 111, D10102, doi:10.1029/2005JD006293, 2006.

Percival, D. B. and Walden, A. T.: Spectral analysis for physical applications: multitaper and conventional univariate techniques, Cambridge University Press, New York, 583 pp., 1993.

Pérez-Ruzafa, A., Marcos, C., Pérez-Ruzafa, I., and Ros, J.: Evolución de las características ambientales y de los poblamientos del Mar Menor (Murcia, SE de España), Anales de Biología, 3, 53 65, 1987.

Pérez-Ruzafa, A., Marcos-Diego, C., and Ros, J.: Environmental and biological changes related to recent human activities in the Mar Menor (SE of Spain), Mar. Pollut. Bull., 23, 747-751, 1991.

Pérez-Ruzafa, A. and Marcos-Diego, C.: Colonization rates and dispersal as essential parameters in the confinement theory to explain the structure and horizontal zonation of lagoon benthic assemblages, Rapp. Comm. int. Mer Médit., 33, p. 100, 1992.

Pérez-Ruzafa, A., Marcos, C., and Gilabert, J.: The ecology of the Mar Menor coastal lagoon: a fast-changing ecosystem under human pressure, Coastal Lagoons, CRC Press, Boca Racon, 392421, 2005

Pirazzoli, P. A.: World atlas of Holocene sea-level changes, Elsev. Oceanogr. Serie., 58, 1-280, 1991.

Raji, O., Dezileau, L., Von Grafenstein, U., Niazi, S., Snoussi, M., and Martinez, P.: Extreme sea events during the last millennium in the northeast of Morocco, Nat. Hazards Earth Syst. Sci., 15, 203-211, doi:10.5194/nhess-15-203-2015, 2015.

Reimer P. J. and McCormac, F. G.: Marine radiocarbon reservoir corrections for the Mediterranean and Aegean seas, Radiocarbon, 44, 159-166, 2002.

Richter, T. O., Van der Gaast, S. J., Koster, B., Vaars, A. J., Gieles, R., De Stigter, H. C., De Haas, H., and VanWeering, T. C. E.: The Avaatech XRF Core Scanner: technical description and applications to NE Atlantic sediments, in: Rothwell, R. G., NewTechniques in Sediment Core Analysis, Special Publications, Geological Society, London, 39-50, 2006.

Rimbu, N., Lohmann, G., Lorenz, S. J., Kim, J. H., and Schneider, R. R.: Holocene climate variability as derived from alkenone sea surface temperature and coupled ocean-atmosphere model experiments, Clim. Dynam., 23, 215-227, 2004.

Russell, J. M. and Johnson, T. C.: Late Holocene climate change in the North Atlantic and equatorial Africa: Millennialscale ITCZ migration, Geophys. Res. Lett., 32, L17705, doi:10.1029/2005GL023295, 2005.
Russell, J. M., Johnson, T. C., and Talbot, M. R.: A 725 yr cycle in the climate of central Africa during the late Holocene, Geology, 31, 677-680, 2003.

Sabatier, P., Dezileau, L., Blanchemanche, P., Siani, J., Condomines, M., Bentaleb, I., and Piques, G.: Holocene variations of radiocarbon reservoir ages in a Mediterranean lagoonal system, Radiocarbon, 52, 91-102, 2010.

Sabatier, P., Dezileau, L., Colin, C., Briqueu, L., Bouchette, F., Martinez, P., Siani, G., Raynal, O., and Von Grafenstein, U.: 7000 years of paleostorm activity in the NW Mediterranean Sea in response to Holocene climate events, Quaternary Res., 2012, 1-11, 2012.

Sarkar, A., Ramesh, R., Somayajulu, B. L. K., Agnihotri, R., Jull, A. J. T., and Burr, G. S.: High resolution Holocene monsoon record from the eastern Arabian Sea, Earth Planet. Sc. Lett., 177, 209218, 2000.

Scileppi, E. and Donnelly, J. P.: Sedimentary evidence of hurricane strikes inwestern Long Island, NY, Geochem. Geophy. Geosy., 8, Q06011, doi:10.1029/2006GC001463, 2007.

Seisdedos, J., González de Vallejo, L. I., Rodríguez Franco, J. A., Gracia, F. J., De Río, L., and y Garrote, J.: Estudio y cartografía de los peligros naturales costeros de la región de Murcia. Boletín Geológico y Minero, 124, 505-520, 2013.

Siani, G., Paterne, M., Michel, E., Sulpizio, R., Sbrana, A., Arnold, M., and Haddad, G.: Mediterranean sea surface radiocarbon age changes since the last glacial maximum, Science, 294, 19171920, 2001.

Soon, W., Velasco Herrera, V. M., Selvaraj, K., Traversi, R., Usoskin, I., Arthur Chen, C.-T., Lou, J.-Y., Kao, S.-J., Carter, R. M., Pipin, V., Severi, M., and Becagli, S.: A review of Holocene solar-linked climatic variation on centennial to millennial timescales: Physical processes, interpretative frameworks and a new multiple cross-wavelet transform algorithm, Earth-Sci. Rev., 134, 1-15, 2014.

Staubwasser, M., Sirocko, F., Grootes, P. M., and Segl, M.: Climate change at the $4.2 \mathrm{ka} \mathrm{BP}$ termination of the Indus valley civilization and Holocene south Asian monsoon variability, Geophys. Res. Lett., 30, 1425, doi:10.1029/2002GL016822, 2003.

Thomson, D. J.: Spectrum estimation and harmonic analysis, P. IEEE, 70, 1055-1096, 1982.

Thomson, D. J.: Time series analysis of Holocene climate data, Philos. T. R. Soc. S.-A, 330, 601-616, 1990.

Trigo, I. F., Davies, T. D., and Bigg, G. R.: Decline in Mediterranean rainfall caused by weakening of Mediterranean cyclones, Geophys. Res. Lett., 27, 2913-2916, 2000.

Von Rad, U., Schaaf, M., Michels, K. H., Schulz, H., Berger, W. H., and Sirocko, F.: A 5000-yr Record of Climate Change in Varved Sediments from the Oxygen Minimum Zone off Pakistan, Northeastern Arabian Sea, Quaternary Res., 51, 39-53, 1999.

Wang, L., Sarnthein, M., Erlenkeuser, H., Grimalt, J., Grootes, P., Heilig, S., Ivanova, E., Kienast, M., Pelejero, C., and Pflaumann, U.: East Asian monsoon climate during the Late Pleistocene: high-resolution sediment records from the South China Sea, Mar Geol., 156, 245-284, 1999.

Wang, X. and Liu, P. L.-F.: A numerical investigation of Boumerdes-Zemmouri (Algeria) earthquake and tsunami, Comp. Model. Eng., 10, 171-184, 2005. 
Wanner, H., Solomina, O., Grosjean, M., Ritz, S. P., and Jetel, M.: Structure and origin of Holocene cold events, Quaternary Sci. Rev., 30, 3109-3123, 2011.
Zoppi, U., Albani, A., Ammerman, A. J., Hua, Q., Lawson, E. M., and Serandrei Barbero, R.: Preliminary estimate of the reservoir age in the Lagoon of Venice, Radiocarbon, 43, 489-494, 2001. 